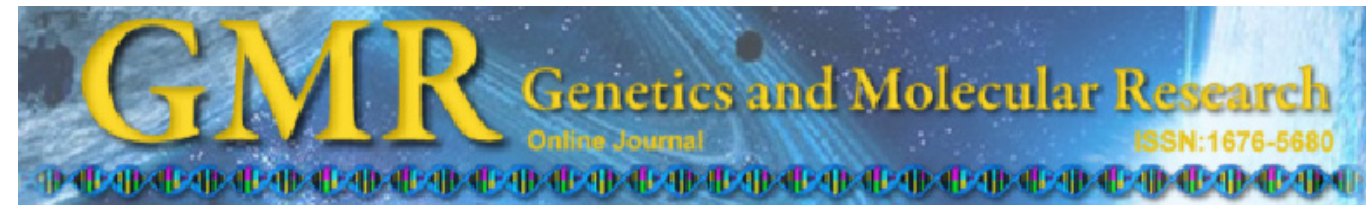

\title{
Lack of an association between a single nucleotide polymorphism in the bovine myogenic determination 1 (MyoD1) gene and meat quality traits in indigenous Chinese cattle breeds
}

\author{
J.A. Ujan', L.S. Zan ${ }^{1,2}$, H.B. Wang ${ }^{1,2}$, S.A. Ujan ${ }^{3}$, C. Adoligbe ${ }^{1}$, \\ H.C. Wang ${ }^{1}$ and S.F. Biao ${ }^{1}$ \\ ${ }^{1}$ College of Animal Science and Technology, Northwest A\&F University, \\ Yangling, Shaanxi, P.R. China \\ ${ }^{2}$ National Beef Cattle Improvement Centre, Yangling, Shaanxi, P.R. China \\ ${ }^{3}$ Government Sachal Sarmast College Ranipur, \\ Shah Abdul Latif University Khairpur, Sindh, Pakistan \\ Corresponding author: L.S. Zan or J.A. Ujan \\ E-mail: zanls@yahoo.com.cn / javed.asrl_nwsuaf@live.com
}

Genet. Mol. Res. 10 (3): 2213-2222 (2011)

Received November 5, 2010

Accepted February 22, 2011

Published September 27, 2011

DOI http://dx.doi.org/10.4238/vol10-3gmr1141

\begin{abstract}
The myogenic determination 1 (MyoD1) gene is a member of the MyoD gene family. It encodes for skeletal musclespecific transcription factors containing highly conserved basic helixloop-helix regions that perform important roles in the initiation, maintenance, and regulation of phenotypic traits. We investigated a new single nucleotide polymorphism (SNP) in the MyoD1 gene to evaluate whether this polymorphism affects meat quality traits in five Chinese indigenous cattle breeds, namely Qinchuan (QC), Xia-Nan $(\mathrm{XN})$, Nan-yang (NY), Luxi (LX), and Jia-xian red (JXR). A C $\rightarrow \mathrm{G}$ transversion at position 624 was detected in exon 1 of the MyoD1 gene; it causes an amino acid substitution $\left({ }^{624} \mathrm{serine} /{ }^{/ 24} \mathrm{cysteine}\right)$. Least squares analysis showed that this SNP is not significantly associated with back
\end{abstract}


fat thickness, eye muscle area, intramuscular fat, or marbling. The $\mathrm{A} / \mathrm{B}$ allelic frequencies in the five breeds were $0.810 / 0.189,0.779 / 0.220$, $0.768 / 0.231,0.820 / 0.180$, and $0.801 / 0.198$, respectively. Based on the $\chi^{2}$ test, the genotype distributions of four cattle breeds (LX, NY, QC, and $\mathrm{XN})$ did not agree with Hardy-Weinberg equilibrium $(\mathrm{P}<0.05)$; one breed (JXR) did not deviate significantly from Hardy-Weinberg equilibrium $(\mathrm{P}>0.05)$. The genotypic frequencies among all five cattle breeds showed moderate diversity $(0.25<$ polymorphism information content $<0.5$ ). We concluded that the C624G SNP of the MyoD1 gene does not influence meat quality traits in indigenous Chinese cattle breeds; however, this SNP could be included in breed composition and population admixture analyses due to the marked differences in allelic frequencies among these five breeds.

Key words: Allelic frequencies; Myogenic determination gene 1; Meat quality; Single nucleotide polymorphism; Qinchuan cattle

\section{INTRODUCTION}

Difference in meat quality is due to variation in different genetic and environmental factors that interact and determine the course of metabolic reactions in muscular tissue and also in the autopsy transition of muscle into meat. A candidate gene access may furnish a more channelize apprehension of the genetic basis for the manifestation of quantitative divergences between individuals (Noguera et al., 2003). The myogenic determination 1 (MyoD1) gene is a member of the MyoD gene family. Myogenesis, a complex process invoved in muscle fiber formation throughout embryonic development, differentiation and maturation (Pette and Staron, 1997; te Pas et al., 1994, 1999a), is completely controlled by the MyoD gene family. MyoD1 and MYF5 were believed to be candidate genes for meat production and meat quality (te Pas, 2004; Carmo et al., 2005). In previous studies, polymorphism in the MyoD gene family and the association with carcass, meat quality, and reproduction traits in different pig lines and breeds have been reported (te Pas et al., 1999b; Cieslak et al., 2000; Carmo et al., 2005; Wyszynska-Koko et al., 2006; Humpolíček et al., 2007; Verner et al., 2007). Furthermore, polymorphism in the MyoD gene family and the effects on growth and carcass traits in Korean cattle, Han Woo, have also been reported (Bhuiyan et at., 2009). Yet, very little research has reported on the relationship between polymorphism of the MyoD1 gene and meat quality traits in cattle. We investigated a new single nucleotide polymorphism (SNP) in the MyoD1 gene to evaluate whether this polymorphism affects meat quality traits in Qinchuan cattle, and to estimate the allelic frequencies of five Chinese indigenous cattle breeds, namely Qinchuan (QC), Xia-Nan (XN), Nan-yang (NY), Luxi (LX), and Jia-xian red (JXR).

\section{MATERIAL AND METHODS}

\section{Animals and data collection}

A total of 651 animals from five different cattle breeds, including JXR $(\mathrm{N}=63), \mathrm{LX}$ 
$(\mathrm{N}=125), \mathrm{NY}(\mathrm{N}=67), \mathrm{QC}(\mathrm{N}=267)$, and $\mathrm{XN}(\mathrm{N}=129)$, each two years of age were used in this study. The JXR animals were sampled from the breeding farm of Jiaxian cattle (Jiaxian county, Henan Province, P.R. China); the LX cattle were sampled from the reserve center of Luxi cattle (Heze city, Shandong Province, P.R. China); the NY animals were sampled from the breeding center of Nanyang cattle (Nanyang city, Henan Province, P.R. China); the QC animals were sampled from the reserve farm of Qinchuan cattle (Weinan city, Shaanxi Province, P.R. China), and the XN animals were from the breeding farm of Xianan cattle (Biyang city, Henan Province, China). The animals were cared and selected according to the standards of the Canadian council on Animal care (MacNeil and Newman, 1994). All the breeding populations of these cattle were used to analyze the allelic frequencies of the MyoD1 gene. However, QC cattle $(\mathrm{N}=163)$ were only used for the association study. The meat quality traits were calculated as previously described (Gilbert et al., 1993), including back fat thickness (BFT), eye muscle area (EMA), intramuscular fat (IF), and marbling (Mb). Mb for meat quality grade was calculated from a cross-section of the loin muscle between the 12th and 13th rib, which is scored on a scale from 1 to 5 .

\section{DNA extraction and polymerase chain reaction (PCR) amplification}

Six hundred and fifty-one blood samples were taken from these five indigenous Chinese cattle breeds. DNA samples were extracted from leukocytes and isolated from acid citrate dextrose (ACD) blood samples (ACD:blood, 1:6), treated with 2\% heparin, and stored at $-80^{\circ} \mathrm{C}$, following standard procedures (Sambrook and Russell, 2002). Twelve primer pairs were designed based on the NCBI database, according to the sequence of the bovine MyoD1 gene (GenBank accession No. NC_007313.3) to amplify both exon and intron regions in the MyoD1 gene using the Primer 3 program (http://frodo.wi.mit.edu/). Detailed information on oligonucleotide primers, amplicon size, and corresponding annealing temperature is depicted in Table 1.

PCR amplifications were performed in a $20-\mu \mathrm{L}$ reaction mixture with $50 \mathrm{ng}$ template DNA, $10 \mathrm{pM}$ of each primer, $0.20 \mathrm{mM} \mathrm{dNTP}, 2.5 \mathrm{mM} \mathrm{MgCl}_{2}$, and $0.5 \mathrm{U}$ Taq DNA polymerase (TaKaRa, Dalian, China). The PCR was run under the following conditions: initial denaturation at $95^{\circ} \mathrm{C}$ for $5 \mathrm{~min}, 32$ cycles of denaturation at $94^{\circ} \mathrm{C}$ for $30 \mathrm{~s}, 58^{\circ} \mathrm{C}$ annealing temperature for $30 \mathrm{~s}$, extension at $72^{\circ} \mathrm{C}$ for $30 \mathrm{~s}$, and a final extension at $72^{\circ} \mathrm{C}$ for $10 \mathrm{~min}$. Electrophoresis of PCR product was performed on 1.5\% agarose gels (stained with $200 \mathrm{ng} / \mathrm{mL}$ ethidium bromide) using 1 X TBE buffer ( $89 \mathrm{mM}$ Tris, $89 \mathrm{mM}$ boric acid, $2 \mathrm{mM} \mathrm{Na} \mathrm{EDTA}_{2}$.

The PCR products were purified with the Wizard Prep PCR purification kit (Shanghai Bioasia Biotechnology, P.R. China) and sequenced in the ABI PRIZM 3730 DNA sequencer (Perkin-Elmer Shanghai Sangon Biological Engineering Technology, Ltd.). DNA polymorphisms were analyzed by comparing the sequence data with sequences in the NCBI database (http://www.ncbi.nlm.nih.gov) using the DNAMAN software (version 6.0). The sequencing map of the novel SNP of the bovine MyoD1 exon 1 region revealed a $\mathrm{C}>\mathrm{G}$ mutation at $166 \mathrm{bp}$ using the Chromas 2.33 version software (http://www.technelysium. com.au/) (see Figure 3). 


\begin{tabular}{|c|c|c|c|}
\hline Gene (accession No.) & Oligonucleotide sequence (5' to $3^{\prime}$ ) & Amplicon size (bp) & Annealing temperature $\left({ }^{\circ} \mathrm{C}\right)$ \\
\hline \multirow[t]{22}{*}{ MyoD1 (NC_007313) } & F: ACCCTCAGTGCTTTGCTATCTC & 136 & 60 \\
\hline & R: GGCGACAGCAGCTCCATA & & \\
\hline & F: AGCAAGTTTCTGGCAACCC & 166 & 60 \\
\hline & R: CATAGAAGTCGTCCGCTGTTG & & \\
\hline & F: CAACAGCGGACGACTTCTATG & 127 & 56 \\
\hline & R: GGGAAGTGCGAGTGTTCCTC & & \\
\hline & F: CCGAGGAACACTCGCACTT & 150 & 56 \\
\hline & R: CGGCGTTAGTCGTCTTGC & & \\
\hline & F: AAACGCAAGACGACTAACGC & 166 & 58 \\
\hline & R: TATAGCGGATGGCGTTGC & & \\
\hline & F: GCCTGAGCAAAGTCAACGAG & 266 & 60 \\
\hline & R: GCCGTCGGAACAGTTGGA & & \\
\hline & F: AAAGGGCATGTGGGAAGG & 210 & 58 \\
\hline & R: CTCAGAGCACCTGGTAAATCG & & \\
\hline & F: CTCAGAGCACCTGGTAAATCG & 190 & 58 \\
\hline & R: CACAACAGTTCCTTCGCCTCT & & \\
\hline & F: AGAGGCGAAGGAACTGTTGT & 129 & 60 \\
\hline & R: GCCCACGGAGTAACATCAAA & & \\
\hline & F: TCCCTGAGACCCGCTGTG & 231 & 60 \\
\hline & R: TGTTACACTTGGGAAGGGAGC & & \\
\hline & F: GACCGCTTAAAGGGGCGT & 194 & 58 \\
\hline & R: GCTCTGGCAAAGCAACTCTTAT & & \\
\hline
\end{tabular}

\section{PCR-SSCP analyses}

The PCR products were analyzed for single-strand conformation polymorphisms (SSCP). Aliquots of $4 \mu \mathrm{L}$ of the above PCR products were combined with $8 \mu \mathrm{L}$ denaturing solution ( $95 \%$ formamide, $25 \mathrm{mM}$ EDTA, $0.025 \%$ xylene-cyanole, and $0.025 \%$ bromophenol blue), incubated at $98^{\circ} \mathrm{C}$ for $10 \mathrm{~min}$, and then chilled on ice. Denatured DNA was loaded onto $10 \%$ PAGE gel in $1 \mathrm{X}$ TBE buffer under a constant voltage of $120 \mathrm{~V}$ for $12 \mathrm{~h}$. Finally, the gel was stained with $0.1 \%$ silver nitrate and visualized and developed with $2 \% \mathrm{NaOH}$ solution (containing $0.1 \%$ formaldehyde), according to Zhang et al. (2007).

\section{Statistical analysis}

Genotype and allele frequencies of each of the above-mentioned Chinese indigenous cattle breeds were calculated directly. The parameters of population genetic indices, $H_{\mathrm{E}}$ (gene heterozygosity), $H_{\mathrm{O}}$ (gene homozygosity), $N_{\mathrm{e}}$ (effective allele numbers), and PIC (polymorphism information content), were determined according to Nei and Roychoudhury (1974) and Nei and Li (1979). The differences in genotypic frequencies of SNP were determined for deviations from Hardy-Weinberg equilibrium by mean values $\pm \mathrm{SE}$, which were performed by using the Statistical Product and Service Solutions software (SPSS, version 17.0). Statistical analysis for associations between MyoD1 genotypes and meat quality traits of Qinchuan cattle was performed using the SPSS software (version 17.0). The following linear model was applied for analysis, which included fixed effects of sex, age and genotype.

$$
Y_{i j k}=\mu+A_{i}+G_{j}+S_{K}+E_{i j k}
$$

(Equation 1) 
where $Y_{i j k}$ stands for the observed value of body measurement trait, $\mu$ for the overall population mean, $A_{i}$ for the fixed effect of the $i$ th age, $G_{i}$ for the fixed effect of $j$ th genotype (AA and AB genotypes), $S_{K}$ for the fixed effect of sex, and $E_{i j k}$ for the random error.

\section{RESULTS}

\section{SNP and genotype frequencies of different populations}

A 166-bp portion of the amplified product was PCR amplified in all animals (Figure 1). After PCR-SSCP amplification (Figure 2) and sequencing of a 166-bp fragment, we discovered a single novel SNP at C624G in exon 1 of the MyoD 1 gene (GenBank accession No. $\mathrm{NC} \_007313.3$ ) in 651 animals. This $\mathrm{C} \rightarrow \mathrm{G}$ mutation at 624 bp was a point mutation (transversion), which induced a change from serine (TCT) to cysteine (TGT). The SNP (C624G) exhibited two different patterns in the population (Figures 2 and 3). For identification, we assigned $\mathrm{AA}$ with three bands and $\mathrm{AB}$ with four bands. The sequencing map of the novel SNP of the bovine MyoD1 exon 1 region also depicted a synonymous mutation $\mathrm{C}>\mathrm{G}$ (Figure 3).

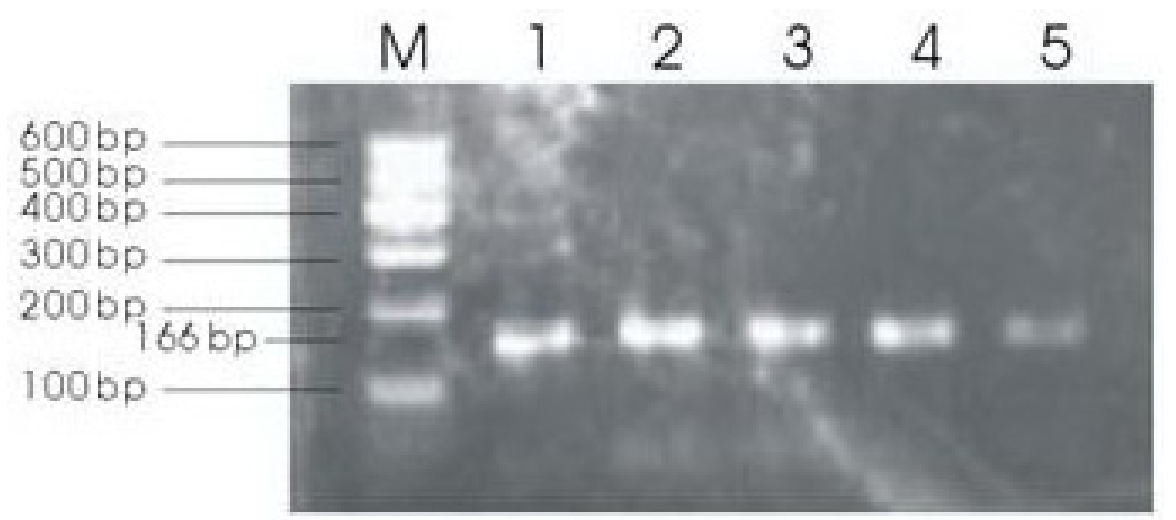

Figure 1. PCR product of the MyoD1 gene exon 1 and its flanking region. $\mathrm{M}=$ molecular marker; lanes $1-5=\mathrm{PCR}$ products of the MyoD1 gene exon 1 and its flanking region.

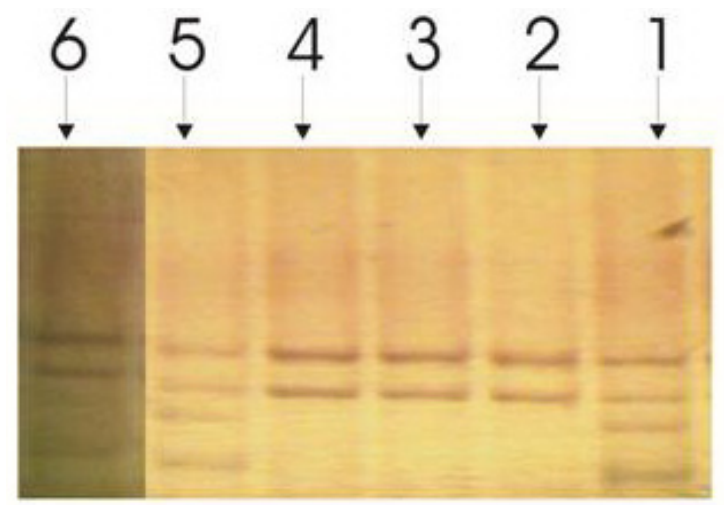

Figure 2. The PAGE electrophoresis patterns of PCR-SSCP exon 1 of the bovine MyoD1 gene. Lanes 2, 3 and $4=$ genotype AA; lanes 1,5 and $6=$ genotype $\mathrm{AB}$. 

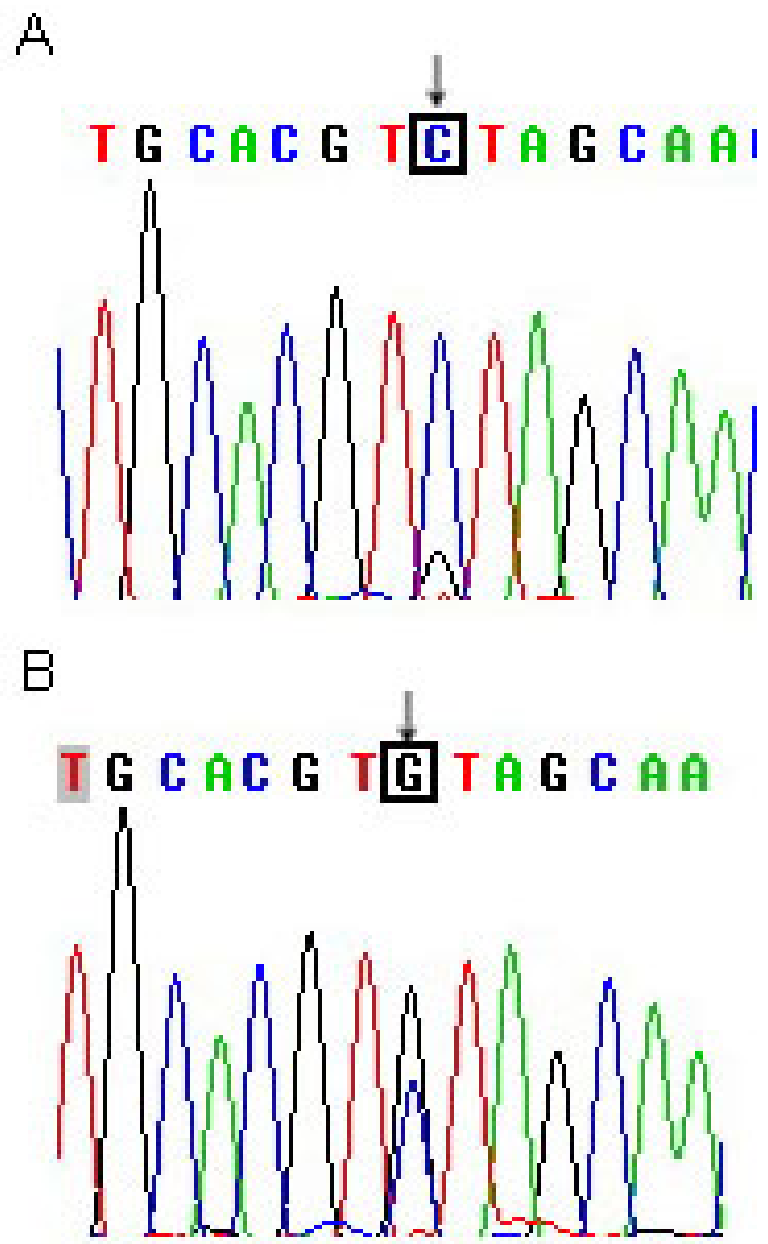

Figure 3. Sequencing map of the novel SNP of the bovine MyoD1 exon 1 region. This map reveals a $\mathrm{C} \rightarrow \mathrm{G}$ (A and B, respectively) mutation at $166 \mathrm{bp}$.

Allelic frequencies of the SNP were then determined and calculated by the $\chi^{2}$ test in all the cattle populations (JXR, LX, NY, QC, and XN); results varied from 0.180 to 0.820 (Table 2). The genotype distributions among four cattle breeds, LX, NY, QC, and XN, did not agree with Hardy-Weinberg equilibrium and showed significant differences in allelic frequencies $(\mathrm{P}$ $<0.05$ ). Results for the JXR breed, however, agreed with Hardy-Weinberg equilibrium and did not show any significant difference in allelic frequency $(\mathrm{P}>0.05$; Table 2$)$. The genotypic frequencies among all five cattle breeds showed moderate diversity $(0.25<$ PIC value $<0.5)$. The AA genotype was dominant in all populations, ranging from 0.537 to 0.640 , and the $\mathrm{AB}$ genotype frequency was lowest in all populations, ranging from 0.360 to 0.462 . The BB homozygous genotype was not found in all the populations, possibly because: 1) the very low frequency of the BB genotype in homozygous condition; 2) homozygous BB null is lethal for the above said gene in Chinese cattle breeds; 3 ) it may not exist in native Chinese cattle breeds. 
Table 2. Genotypic, allelic frequencies and population genetic indices at the bovine MyoD1 gene locus in five Chinese indigenous cattle breeds.

\begin{tabular}{|c|c|c|c|c|c|c|c|c|c|}
\hline \multirow[t]{2}{*}{ Breeds } & \multicolumn{2}{|c|}{ Genotypic frequency $(\mathrm{N})$} & \multirow[t]{2}{*}{ Total } & \multicolumn{2}{|c|}{ Allele frequency } & \multirow[t]{2}{*}{$N_{\mathrm{e}}$} & \multirow[t]{2}{*}{ PIC } & \multirow[t]{2}{*}{$H_{\mathrm{E}}$} & \multirow[t]{2}{*}{$\chi^{2}(\mathrm{HWE}$} \\
\hline & AA & $\mathrm{AB}$ & & A & $\mathrm{B}$ & & & & \\
\hline JXR & $0.603(38)$ & $0.396(25)$ & 63 & 0.801 & 0.198 & 1.466 & 0.267 & 0.318 & 2.670 \\
\hline LX & $0.640(80)$ & $0.360(45)$ & 125 & 0.820 & 0.180 & 1.418 & 0.251 & 0.295 & 4.827 \\
\hline NY & $0.537(36)$ & $0.462(31)$ & 67 & 0.768 & 0.231 & 1.551 & 0.292 & 0.355 & 4.764 \\
\hline QC & $0.621(166)$ & $0.378(101)$ & 267 & 0.810 & 0.189 & 1.442 & 0.259 & 0.306 & 14.527 \\
\hline $\mathrm{XN}$ & $0.558(72)$ & $0.441(57)$ & 129 & 0.779 & 0.220 & 1.524 & 0.285 & 0.344 & 10.374 \\
\hline
\end{tabular}

$\mathrm{N}=$ number of observations; $N_{\mathrm{e}}=$ effective allele number; PIC = polymorphism information content; $H_{\mathrm{E}}=$ expected heterozygosity; $\chi^{2}(\mathrm{HWE})=$ Hardy-Weinberg equilibrium $\chi^{2}$ value. JXR = Jia-xian red cattle; LX $=$ Luxi cattle; NY $=$ Nan-yang cattle; $\mathrm{QC}=$ Qinchuan cattle; XN = Xia-Nan cattle. The P values for JXR, LX, and NY were below 0.05 and for $\mathrm{QC}$ and $\mathrm{XN}$ were below 0.01 .

$H_{\mathrm{E}}, N_{\mathrm{e}}$, and PIC of the MyoD1 gene locus in these five populations of Bos taurus varied from 0.295 to $0.355,1.418$ to 1.551 , and 0.251 to 0.292 , respectively. As per the general trend, PIC was classified into three types: low polymorphism (PIC $<0.25$ ), median polymorphism $(0.25<$ PIC value $<0.5)$, and high polymorphism (PIC $>0.5)$. While considering the above classification of PIC, all these Bos taurus populations showed a median polymorphism level (Table 2). Therefore, we suggest that the high frequency of the MyoD1-A allele could be used to characterize these Bos taurus breeds.

\section{SNP marker association}

The genotype of 163 individuals of Qinchuan cattle was compared with the phenotypic data for 4 meat quality traits. Least squares analysis showed that the $\mathrm{C} \rightarrow \mathrm{G}$ mutation at $624 \mathrm{bp}$ lacked significant associations $(\mathrm{P}>0.05)$ with BFT, EMA, IF, and Mb. The results of association analysis are depicted in Table 3. Therefore, our data showed non-significant results.

\begin{tabular}{|c|c|c|c|c|c|}
\hline \multirow[t]{2}{*}{ Breed } & \multirow[t]{2}{*}{ Genotype } & \multicolumn{4}{|c|}{ Meat quality traits $(\mathrm{cm})$} \\
\hline & & BFT & EMA & IF & $\mathrm{Mb}$ \\
\hline \multirow[t]{3}{*}{ Qinchuan } & AA & $0.39 \pm 0.01$ & $35.6 \pm 1.01$ & $7.7 \pm 0.08$ & $3.4 \pm 0.08$ \\
\hline & $\mathrm{AB}$ & $0.38 \pm 0.01$ & $36.9 \pm 1.08$ & $7.8 \pm 0.09$ & $3.3 \pm 0.09$ \\
\hline & & 0.755 & 0.164 & 0.855 & 0.671 \\
\hline
\end{tabular}

\section{DISCUSSION}

At present, breeding goals are changing from high yield, to more meat quality traits (van Wijk et al., 2005). Study of association with a candidate gene is a step towards better comprehension of the genetic basis of productive traits (O'vilo et al., 2006). Mutation in the candidate genes and its association with economic attributes have been studied to ascertain the genetic basis of quality traits and to develop marker-assisted selection. Myogenesis and postnatal tissue growth are determined by the muscle-regulatory factor gene family (MyoD1), 
comprised of four genes (MyoD1, MYF4, MYF5, and MYF6). Their mutations have been described in several pig breeds and pig lines to affect the meat loosening in the carcass (Cieslak et al., 2002; Kuryl et al., 2002) and the micro-structural features of muscle tissue (Klosowska and Fiedler, 2003; Klosowska et al., 2001, 2004). Nevertheless, there have been very few studies on the MyoD1 gene in cattle.

We found lack of association between SNPs in the bovine MyoD1 gene and meat quality traits in the Qinchuan cattle population, and showed that the exon 1, 624 bp, C>G synonymous mutation is not significantly associated with BFT, EMA, IF, or Mb. These results are consistent with various previous investigations, which found non-significant relationships between MyoD1 gene polymorphisms and growth and meat quality traits (Cieslak et al., 2002; Kapelanski et al., 2005). Similar results were also found for the MyoD1/DdeI polymorphism that is in the non-coding region (intron 1) of the MyoD1 gene (Knoll et al., 1997).

Another scientist, Cieslak et al. (2000), also found lack of significant effects of MyoD1 genotypes on carcass quality attributes among 115 Torhyb pigs of both sexes. Kuryl et al. (2002) reported that the effect of the MyoD1 locus genotypes on carcass quality varies in breeds and lines. The pig MyoD1 gene also may lack a significant mutation impacting these attributes, or else the linkage phase of MyoD1/DdeI polymorphism with a MyoD1 mutation does not provide objective information (te Pas et al., 1999a). Liu et al. (2008) also reported a lack of association between polymorphism of MyoD1/DdeI with meat quality traits in Large White 9 Meishan $\mathrm{F}_{2}$ populations.

Although we did not find any significant association, it is possible that other SNPs in the MyoD1 gene are correlated with IMF or Mb, or with other meat quality traits. However, some contrary results have been reported for the bovine MyoD1 gene, both in coding and non-coding regions (te Pas et al., 2000; Wojciech et al., 2005; Verner et al., 2007; Estellé et al., 2008). The MyoD1 gene is also considered as a potential candidate gene for meat tenderness and carcass traits (Rexroad III et al., 2001; Casas et al., 2003). Summing up the results of the research performed on several breeds and lines of pigs and cattle, one may conclude that the significant effect of genotype at the MyoD1 locus on carcass and meat quality depends on breed or line. Some researchers have explained the differences in results to be due to the use of different methods (PCR versus Southern blotting; see, te Pas and Visscher, 1994). In addition, knockout mouse experiments revealed that MyoD1 and MYF5 genes are to a certain degree redundant, which may also decrease mutation effects (Rudnicki et al., 1993; Cieslak et al., 2002).

We conclude that no significant association exists between meat quality traits and the corresponding genotypes for these MyoD1 gene polymorphisms in the Qinchuan cattle breed. This result is consistent with previous studies on other bovine and porcine populations.

\section{CONCLUSIONS}

Associations between SNPs of MyoD1 and meat quality traits were studied in commercial lines of Qinchuan cattle. No genotype was significantly associated with BFT, EMA, $\mathrm{IF}$, or $\mathrm{Mb}$. We suggest that this SNP could be considered as a part of marker panels for breed composition and population admixture analyses due to the marked differences in allelic frequencies among these native Chinese cattle breeds. 


\section{ACKNOWLEDGMENTS}

The authors thank Dr. H.B. Wang for his valuable comments. Research supported by the National "863" Program of China (\#2006AA10Z1A1, \#2008AA101010, and \#2010AA10Z101), the Program for Changjiang Scholars and Innovative Research Team (\#IRT0940), and the "13115" Scientific and Technological Innovation Program of Shaanxi Province (\#2007ZDCY-01).

\section{REFERENCES}

Bhuiyan MSA, Kim NK, Cho YM, Yoon D, et al. (2009). Identification of SNPs in MYOD gene family and their associations with carcass traits in cattle. Livest. Sci. 126: 292-297.

Carmo FMS, Guimarães SEF, Lopes PS, Pires AV, et al. (2005). Association of MYF5 gene allelic variants with production traits in pigs. Genet. Mol. Biol. 28: 363-369.

Casas E, Shackelford SD, Keele JW, Koohmaraie M, et al. (2003). Detection of quantitative trait loci for growth and carcass composition in cattle. J. Anim. Sci. 81: 2976-2983.

Cieslak D, Kapelanski W, Blicharski T and Pierzchala M (2000). Restriction fragment length polymorphisms in myogenin and myf3 genes and their influence on lean meat content in pigs. J. Anim. Breed. Genet. 117: 43-55.

Cieslak D, Kuryl J, Kapelañski W, Pierzchala M, et al. (2002). A relationship between genotypes at MYOG, MYF3 and MYF5 loci and carcass meat and fat deposition traits in pigs. Anim. Sci. Pap. Rep. 20: 77-92.

Estellé J, Gil F, Vázquez JM, Latorre R, et al. (2008). A QTL genome scan for porcine muscle fiber traits reveals over dominance and epistasis. J. Anim. Sci. 86: 3290-3299.

Gilbert RP, Bailey DR and Shannon NH (1993). Linear body measurements of cattle before and after 20 years of selection for postweaning gain when fed two different diets. J. Anim. Sci. 71: 1712-1720.

Humpolíček P, Urban T and Tvrdon Z (2007). Relation of porcinemyogenin gene PCR/RFLP MspI and reproduction traits of the Czech Large White sows. Livest. Sci. 110: 288-291.

Kapelanski W, Grajewska S, Kuryl J, Bocian M et al. (2005). Polymorphism in coding and non coding regions of the MYOD gene family and meat quality in pigs. Fol. Biol. 53: 45-49.

Klosowska D and Fiedler I (2003). Muscle fiber types in pigs of different genotypes in relation to meat quality. Anim. Sci. Pap. Rep. 21 (Suppl 1): 49-60.

Klosowska D, Kuryl J, Cieoelak D and Elminowska-Wenda G (2001). The relationship between polymorphisms in porcine MYOG, MYF-3 and MYF-5 genes and micro-structural characteristics of longissimus muscle - a preliminary study. In: 47th Intern. Congress of Meat Sci. Technology, Kraków, 142-143.

Klosowska D, Kuryl J, Elminowska-Wenda G and Kapelanski W (2004). A relationship between the PCR-RFLP polymorphism in porcine MYOG, MYOD 1 and MYF5 genes and microstructural characteristics of $\mathrm{m}$. longissimus lumborum in Pietrain $\times$ (Polish Large White $\times$ Polish Landrace) crosses. Czech J. Anim. Sci. 49: 99-107.

Knoll A, Nebola M, Dvorak J and Cepica S (1997). Detection of a DdeI PCR RFLP within intron 1 of the porcine MYOD1 (MYF3) locus. Anim. Genet. 28: 321.

Kuryl J, Kapelañski W, Cieoelak D, Pierzchala M et al. (2002). Are polymorphisms in non-coding regions of porcine MyoD genes suitable for predicting meat and fat deposition in the carcass. Anim. Sci. Pap. Rep. 20: 245-254.

Liu M, Peng J, Xu DQ, Zheng R, et al. (2008). Association of MYF5 and MYOD1 gene polymorphisms and meat quality traits in Large White x Meishan F2 pig populations. Biochem. Genet. 46: 720-732.

MacNeil MD and Newman S (1994). Selection indices for Canadian beef production using specialized sire and dam lines. Can. J. Animal Sci. 74: 419-424.

Nei M and Roychoudhury AK (1974). Sampling variances of heterozygosity and genetic distance. Genetics 76: 379-390.

Nei M and Li WH (1979). Mathematical model for studying genetic variation in terms of restriction endonucleases. Proc. Natl. Acad. Sci. U. S. A. 76: 5269-5273.

Noguera JL, Varona L, Gómez-Raya L, Sánchez A, et al. (2003). Estrogen receptor polymorphism in Landrace pigs and its association with litter size performance. Livest. Prod. Sci. 82: 53-59.

O'vilo C, Fernandez A, Rodriguez MC, Nieto M, et al. (2006). Association of MC4R gene variants with growth, fatness, carcass composition and meat and fat quality traits in heavy pigs. Meat Sci. 73: 42-47.

Pette D and Staron RS (1997). Mammalian skeletal muscle fiber type transitions. Int. Rev. Cytol. 170: 143-223.

Rexroad CE III, Bennett GL, Stone RT, Keele JW, et al. (2001). Comparative mapping of BTA15 and HSA11 including a 
region containing a QTL for meat tenderness. Mamm. Genome 12: 561-565.

Rudnicki MA, Schnegelsberg PN, Stead RH, Braun T, et al. (1993). MyoD or Myf-5 is required for the formation of skeletal muscle. Cell 75: 1351-1359.

Sambrook J and Russell DW (2002). Translated by Huang, P. T. Molecular Cloning a Laboratory Manual. 3rd. edn. Science Press, Beijing.

te Pas MF (2004). Candidate genes for meat production and meat quality: the MRF genes. Anim. Sci. Pap. Rep. 22: 115-118.

te Pas MF and Visscher AH (1994). Genetic regulation of meat production by embryonic muscle formation - a review. $J$. Anim. Breed. Genet. 111: 404-412.

te Pas MF, Devries AG and Visscher AH (1994). The MyoD gene Family and Meat Production - A Review. In: Proc. 40th Inter. Congress of Meat Sci. Technology, Hague, S-VII-08.1-6.

te Pas MF, Harders FL, Soumillion A, Born L, et al. (1999a). Genetic variation at the porcine MYF-5 gene locus. Lack Of association with meat production traits. Mamm. Genome 10: 123-127.

te Pas MF, Soumillion A, Harders FL and Verburg FJ (1999b). Influences of Myogenin genotypes on birth weight, growth rate, carcass weight, backfat thickness, and lean weight of pigs. J. Anim. Sci. 77: 2352-2356.

te Pas MF, Verburg FJ, Gerritsen CL and de Greef KH (2000). Messenger ribonucleic acid expression of the MyoD gene family in muscle tissue at slaughter in relation to selection for porcine growth rate. J. Anim. Sci. 78: 69-77.

Van Wijk HJ, Arts DJ, Matthews JO, Webster M, et al. (2005). Genetic parameters for carcass composition and pork quality estimated in a commercial production chain 1. J. Anim. Sci. 83: 324-333.

Verner J, Humpolicek P and Knoll A (2007). Impact of MYOD family genes on pork traits in Large White and Landrace pigs. J. Anim. Breed. Genet. 124: 81-85.

Wojciech K, Salomea G, Jolanta K and Maria B (2005). Polymorphism in coding and non-coding regions of the $M y o D$ gene family and meat quality in pigs. Fol. Biol. 53: 45-49.

Wyszynska-Koko J, Pierzchala M, Flisikowski K, Kamyczek M, et al. (2006). Polymorphisms in coding and regulatory regions of the porcine MYF6 and MYOG genes and expression of the MYF6 gene in longissimus dorsi versus production traits in pigs. J. Appl.Genet. 47: 131-138.

Zhang C, Wang Y, Chen H, Lan X, et al. (2007). Enhance the efficiency of single-strand conformation polymorphism analysis by short polyacrylamide gel and modified silver staining. Anal. Biochem. 365: 286-287. 